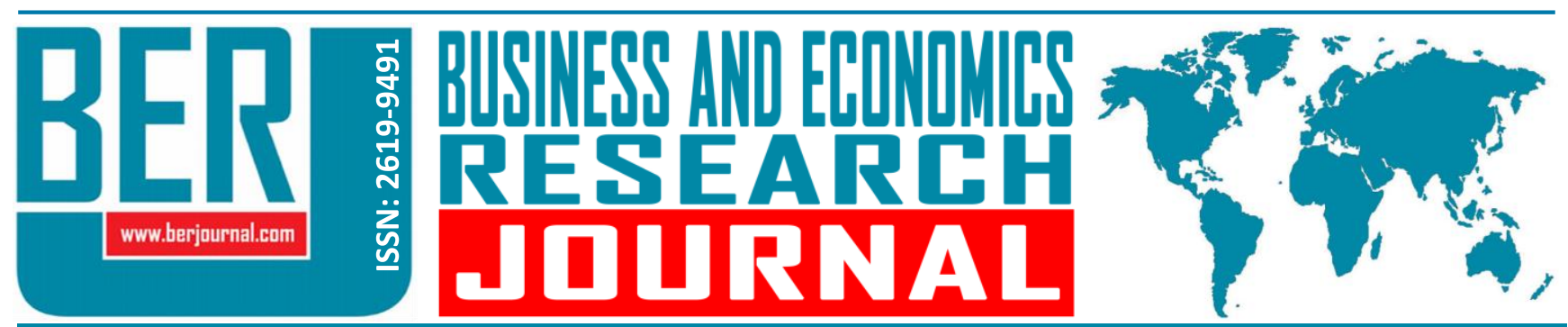

Business and Economics Research Journal Vol. 11, No. 1, 2020, pp. 201-212 doi: 10.20409/berj.2020.245

\title{
The Relationship Between Job Crafting and Organizational Identification: The Mediating Role of Affective Well-being
}

\author{
Eren Kilic ${ }^{\mathrm{a}}$, Berivan Tatar ${ }^{\mathrm{b}}$, Oya Erdil $^{\mathrm{c}}$
}

\begin{abstract}
The aim of this study is to examine the relationship between job crafting and organizational identification along with investigating the mediating role of affective well-being in this relationship. Data gathered from 238 public and private sector employees in Turkey through the survey method was subjected to factor, reliability, convergent and discriminant validity analyses through structural equation modelling. Additionally, the mediating role of affective well-being was tested using PROCESS macro for SPSS. As a result, it was concluded that all aspects of job crafting positively related to positive affection while only task crafting and cognitive crafting were significantly related to negative affection. Besides, positive affection has a positive impact on organizational identification while negative affection has a negative impact. In terms of mediation analyses, positive affection has a partially mediating role in the relationship between all aspects of job crafting and organizational identification while negative affection partially mediates the relationship between task crafting/cognitive crafting and organizational identification.
\end{abstract}

Keywords: Job Crafting, Affective Well-Being, Organizational Identification, Positive Affection, Negative Affection

JEL: D23, I31, M12

$\begin{array}{ll}\text { Received } & : 11 \text { September } 2019 \\ \text { Revised } & : 11 \text { November } 2019 \\ \text { Accepted } & : 21 \text { November } 2019 \\ \text { Type } & : \text { Research }\end{array}$

\section{Introduction}

The main characteristics of professional jobs have been changing because of the revolution of the working environment triggered by organizational innovations which are specially shaped by the rapid development of information technologies and require each organization to create their unique job designs (Demerouti, 2014; Kanten, 2014). According to the traditional approach, designing the job is based on developing the performance and motivation of employees through "top-down" managerial interventions (Hackman \& Oldham, 1980). These managerial interventions could not consider the needs of each employee correctly and have made employees more reactive or passive in organizational processes. However, "bottomup" job redesign approaches have signified that employees have proactive roles rather than passive, which enables them to craft their job characteristics according to their needs (Oldham \& Hackman, 2010; Rofcanin, Berber, Koch, \& Sevinc, 2016). Therefore, employees' proactive work behaviors from the perspective of the bottom-up approach can be used to complement managerial top-down interventions to make up the shortages of current job design and to consider the needs of the employees (Demerouti, 2014).

Cite this article as: Kilic, E., Tatar, B., \& Erdil, O. (2020). The relationship between job crafting and organizational identification: The mediating role of affective well-being. Business and Economics Research Journal, 11(1), 201-212.

The current issue and archive of this Journal is available at: www.berjournal.com

a Res. Asst., Gebze Technical University, Faculty of Business Administration, Kocaeli, Turkiye, erenkilic@gtu.edu.tr (ORCID ID: 0000-0003-4197-8710)

b Res. Asst., Gebze Technical University, Faculty of Business Administration, Kocaeli, Turkiye, btatar@gtu.edu.tr (ORCID ID: 00000002-0934-3734

Prof., PhD., Gebze Technical University, Faculty of Business Administration, Kocaeli, Turkiye, erdil@gtu.edu.tr (ORCID ID: 00000003-3793-001X) 
As a work-specific form of proactive behavior, job crafting refers to the behaviors including to take an active role in initiating changes on cognitive, relational, and physical/task boundaries of current job activities (Wrzesniewski \& Dutton, 2001). Cognitive changes specify an individual's perception of the job, relational changes refer to changing the amount or quality of interactions in the workplace, and changes in physical boundaries indicate initiating changes in the number or type of work activities (Wrzesniewski \& Dutton, 2001). Employees can optimize the balance between what they desire to do and what the job requires from them through crafting behaviors in the workplace according to their needs and values (Tims \& Bakker, 2010). Therefore, person-job fit can be enhanced via better accordance between employees' personal attributes and the job environment (Berg, Wrzesniewski, \& Dutton, 2010).

Relevant literature indicates that job crafting behaviors are positively related to a variety of positive outcomes such as work performance, work engagement, job satisfaction, and employee well-being (Rudolph, Katz, Lavigne, \& Zacher, 2017). Especially, a certain amount of studies indicates that crafting behaviors in the workplace provide enhancing well-being and positive affection because employees may be perceiving to have better control over the work environment through crafting the job (Tims, Bakker, \& Derks, 2013; Slemp, Kern, \& Vella-Brodrick, 2015; Bakker \& Demerouti, 2017). While many studies have indicated that employee's perception of organizational identification is associated with positive organizational attitudes and behaviors (van Knippenberg \& van Schie, 2000), a limited number of studies have examined the relationship between proactive behaviors and perceptions of organizational identification (Klimchak, Carsten, Morrell, \& MacKenzie, 2016; Hur, Shin, Rhee, \& Kim, 2017; Bacaksiz, Tuna, \& Seren, 2017). In this sense, with focusing on job crafting, it is aimed to elucidate the relationship between job crafting behaviors and perceptions of organizational identification and to explore the mediating role of job-related affective well-being in this relationship.

\section{Literature Review and Hypotheses}

\subsection{Job Crafting}

Proactive behaviors such as altering definite work tasks that are faulty or suggesting creative solutions to the current problems are very precious for an organization since these behaviors increase the organization's chance of surviving in the quickly varying competition environment (Tims \& Bakker, 2010; Parker, Bindl, \& Strauss, 2010). As a specific form of proactive behavior, job crafting is defined as "...the physical and cognitive changes individuals make in the task or relational boundaries of their work" (Wrzesniewski \& Dutton, 2001: 179). By crafting the job, employees take an active role rather than passive in initiating changes over the physical, cognitive, or social structures of their jobs and use their hidden ways of freedom in own jobs to customize it in order to make a fit between their needs and jobs (Wrzesniewski \& Dutton, 2001; Slemp \& Vella-Brodrick, 2014; Slemp et al., 2015). Additionally, job crafting also refers to an informal process that employees use to form their work practice with the aim of meeting their needs and individualistic interests (Berg et al., 2010; Slemp \& Vella-Brodrick, 2013).

On the other hand, the concept of job crafting has been discussed from the perspective of the Job Demands-Resources Model (Demerouti, Nachreiner, Bakker, \& Schaufeli, 2001; Bakker \& Demerouti, 2007), and job crafting means personal alterations in job characteristics on organizational, social, and physical level to hold the balance between job demands (e.g. excessive workload, emotionally demanding interactions, time pressure) and job resources such as autonomy, job security, feedback, role clarity (Tims \& Bakker, 2010; Bipp \& Demerouti, 2015). With this regard, the Job Demands-Resources Model implies that when an individual perceives that job demands in the work environment are high and job resources are low, job strain is experienced by the individual (Demerouti, 2014). In this sense, individuals aim to achieve equilibrium between job demands and resources in order to overcome job stress and protect his/her psychological health by making some changes and crafting their jobs in the work environment (Tims \& Bakker, 2010).

In this context, job crafters are employees who act in a proactive stance by changing a job's task, relational and cognitive boundaries at the organization. In doing so, employees change the meaning of the work for own and reshape their work identity in the organizational process (Wrzesniewski \& Dutton, 2001). 
Thus, job crafting is categorized into three forms which are a task, relational and cognitive crafting (Wrzesniewski \& Dutton, 2001; Slemp \& Vella-Brodrick, 2013). Task crafting refers to an employee's proactive modifications over the amount, extent or types of work tasks (Slemp et al., 2015). Crafting task boundaries of the job includes proactive behaviors such as creating specific ways or taking more responsibility for work tasks (Wrzesniewski, Lobuglio, Dutton, \& Berg, 2013). Relational crafting includes employees' alterations over the amount or status of interpersonal interactions with others at the organization (Slemp et al., 2015). Employees determine how often they interact with whom and how these relations' quality should be by crafting relational boundaries (Wrzesniewski \& Dutton, 2001). Finally, cognitive crafting indicates changes over the employees' approaches to their jobs and perceptions relating to their work tasks (Wrzesniewski \& Dutton, 2001). Employees review and shape the main purpose of their jobs as a whole by modifying cognitive boundaries (Kim, Im, \& Qu, 2018). These three forms of job crafting signify particular ways in which employees make proactive alterations and help them to hinder work dissatisfaction and meaninglessness (Wrzesniewski et al., 2013; Slemp \& Vella-Brodrick, 2014).

Job crafting behaviors in the work environment provides increased person-job fit which means what an employee can do and desires to do in the workplace, and what the job requires from the employee are in accordance with each other (Tims \& Bakker, 2010; Niessen, Weseler, \& Kostova, 2016; Kerse, 2018). Because job crafting allows the employees to reshape relational, cognitive, and task context in the workplace, the employees can develop better accordance between their attributes and the job environment (Berg et al., 2010; Rofcanin et al., 2016; Tims, Derks, \& Bakker, 2016). As a result, employees having ability and opportunity to craft their job tend to cultivate positive organizational outcomes such as positive sense of meaningfulness and work identity (Wrzesniewski \& Dutton, 2001; Tims et al., 2016), organizational commitment (Rofcanin et al., 2016), employee retention (Tims \& Bakker, 2010), job satisfaction (de Beer, Tims, \& Bakker, 2016; Rudolph et al., 2017), psychological health (Slemp \& Vella-Brodrick, 2013; 2014; Slemp et al., 2015; Kerse, 2017), work performance (Leana, Appelbaum, \& Shevchuk, 2009; Tims, Bakker, \& Derks, 2012), and work engagement (Bakker, Tims, \& Derks, 2012; Rudolph et al., 2017; Uysal, Özçelik, \& Uyargil, 2018). As a specific form of proactive behavior job crafting, in turn, may help the employees to have a better fit with their jobs, show better performance, commit to their jobs, and be satisfied (Kim et al., 2018). Even though job crafting is not the remedy for all organization problems, it has importance for organizations to manage it in such a way that it has advantageous effects on the organizations and the employees (Demerouti, 2014).

\subsection{Job Crafting and Affective Well-being}

Affective well-being, when considered in the occupational sense, refers to employees' subjective considerations of feeling well or unwell in the workplace (Warr, 1987; 1990b; Makikangas, Feldt, \& Kinnunen, 2007). Job-related affective well-being is explained as an underlying aspect of effective organizations, contributing to desirable organizational outcomes such as enhanced performance and employee retention (Warr, 1990b). In the organizational frame, a variety of studies on affective well-being suggest that a wide range of individual and organizational factors influence employee's affective well-being (Makikangas et al., 2007). In this sense, cultivating individual practices that enhance workplace affective well-being represents substantial initiative for employees, besides this, it may be beneficial for improving organizational effectiveness (Slemp et al., 2015).

Considering as a specific individual practice, proactive behaviors help employees to experience better well-being and positive affection, for the reason that they perceive to have more control and freedom over their working environment (Tims \& Bakker, 2010; Parker et al., 2010). As a job-related form of proactive behavior, job crafting provides employees to align their individual needs with their work requirements, and thus, they improve their well-being by experiencing positive affection (Slemp et al., 2015; Plomp, Tims, Akkermans, Khapova, Jansen, \& Bakker, 2016). Job crafting also brings with positive results to enhance employee's affective well-being such as improving better relationships, enhancing individual purpose and increased job meaning (Slemp \& Vella-Brodrick, 2014). 
Empirical findings in the literature show that crafting behaviors are explained to stimulate more positive affection than negative affection, and thus, positive affection helps to enhance job performance (Bakker \& Demerouti, 2017; Costantini \& Sartori, 2018). By crafting their jobs employees improve their affective well-being with increased engagement, job satisfaction, and decreased burnout (Tims et al., 2013; van den Heuvel, Demerouti, \& Peeters, 2015). Another study indicates that job crafting is positively related to occupational well-being while negatively related to job strain (Rudolph et al., 2017). Studies of Slemp \& Vella-Brodrick (2013) and Slemp, Kern, \& Vella-Brodrick (2015) specify that job crafting behaviors are positively associated with work-specific positive affection, while negatively associated with work-specific negative affection. These findings imply positive relations between job crafting behavior and job-related affective well-being. Hence, the following hypotheses were postulated:

H1: (a) Task crafting, (b) cognitive crafting, and (c) relational crafting is positively related to positive affection.

H2: (a) Task crafting, (b) cognitive crafting, and (c) relational crafting is negatively related to negative affection.

\subsection{Job Crafting and Organizational Identification}

Based on social identity theory (Tajfel, 1974; Tajfel \& Turner, 1985) Mael and Ashforth (1992) defined the concept of organizational identification as "perceived oneness with an organization and the experience of the organization's successes and failures as one's own." According to this definition organizational identification specifies a kind of social identification which includes that individuals identify with the organization where they work, and the organization provides the individuals with an identity perception (Ashforth \& Mael, 1989; van Knippenberg \& van Schie, 2000). Thus, organizational identification refers to the degree of correspondence between one's own identity and the organization's identity (Ashforth \& Mael, 1989; Mael \& Ashforth, 1992).

Research on organizational identification suggests that a variety of organizational and individual factors are related to individuals' perception of organizational identification (van Knippenberg \& van Schie, 2000). Empirical findings from recent studies revealed that employees with an increased perception of organizational identification establish positive attitudes toward it, feel more motivated to show beneficial organizational behaviors, and have the belief that their crafting efforts are valuable for the organization (Hur et al., 2017; Wang, Demerouti, \& Le Blanc, 2017). Conversely, we propose that employees crafting their jobs may tend to identify themselves with their organization. Consistent with this view, studies show that proactive work behaviors that bring with mostly positive outcomes are positively associated with the individuals' perception of organizational identification (Klimchak et al., 2016; Bacaksiz et al., 2017; Hur et al., 2017). Considering the proactive behavior perspective, it can be predicted that job crafting is likely to have a positive relationship with organizational identification. Nevertheless, in the relevant literature, a limited number of studies have investigated the relationship between job crafting and organizational identification (Niessen et al., 2016; Hur et al., 2017). In this sense, it is aimed to clarify the relationship between these concepts. Consequently, it is hypothesized as in the following:

H3: (a) Task crafting, (b) cognitive crafting, and (c) relational crafting is positively related to organizational identification.

\subsection{Mediating Role of Job-related Affective Well-being}

Recent studies indicate that employees who act in a proactive stance in organizing their work environment experience positive affection and improve their job-related affective well-being (Tims \& Bakker, 2010; Slemp \& Vella-Brodrick, 2013; 2014). Job crafting behaviors also help employees to optimize their individual needs with their work activities and develop better well-being (Slemp et al., 2015). Besides, relevant studies show that workplace affective well-being of the employee is positively associated with his/her perception of identifying with the organization (Wegge, van Dick, Fisher, Wecking, \& Moltzen, 2006; Avanzi, van Dick, Fraccaroli, \& Sarchielli, 2012). Thus, it is suggested in this study that employees who enhanced their job-related affective well-being through the crafting behaviors are likely to more identify 
themselves with their organization. With this regard, it is proposed that affective well-being may have a mediating role in the relationships between job crafting and organizational identification. Therefore:

H4: (a) Positive affection and (b) negative affection are related to organizational identification.

H5: Positive affection mediates the relationship between (a) task crafting, (b) cognitive crafting, (c) relational crafting, and organizational identification.

H6: Negative affection mediates the relationship between (a) task crafting, (b) cognitive crafting, (c) relational crafting, and organizational identification.

Figure 1. Research Model

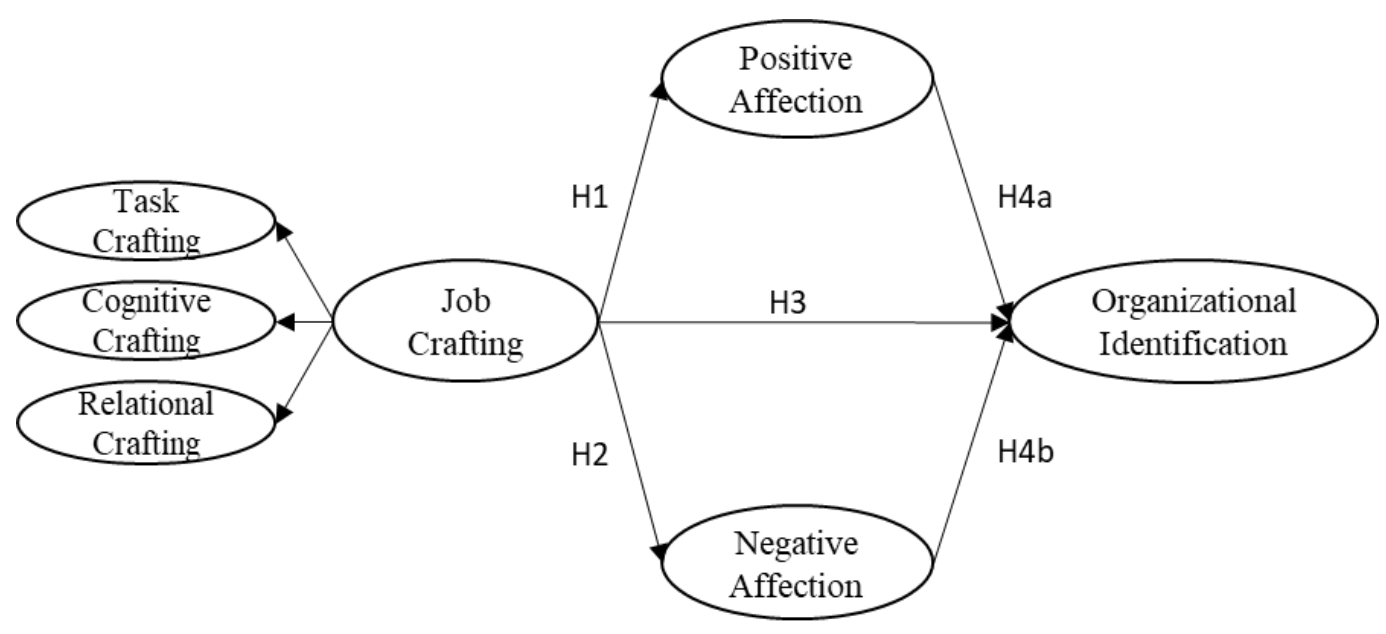

\section{Research Method}

\subsection{Sample and Data Collection}

The aim of the study is to determine the effects of job crafting on organizational identification and examine the mediating role of job-related affective well-being in the relationship between job crafting and organizational identification. For this purpose, a self-administered questionnaire has been used for data collection. In the questionnaire, three different scales were used to measure job crafting, affective wellbeing, and organizational identification. Besides, demographic questions were asked to the participants about their gender, age, working sector and working experience in the current organization.

Table 1. Sample Profile of Participants

\begin{tabular}{lcc}
\hline \multicolumn{1}{c}{ Characteristics } & N & (\%) \\
\hline Gender & & \\
Female & 116 & 48.7 \\
Male & 122 & 51.3 \\
\hline Age & 12 & \\
$18-24$ & 189 & 79.4 \\
$25-34$ & 31 & 13 \\
$35-44$ & 6 & 2.5 \\
$\quad$ More than 45 & 129 & \\
Working Sector & 109 & 54.2 \\
Public Sector & & 45.8 \\
$\quad$ Private Sector & 31 & \\
Working Experience & 151 & 63.4 \\
Below 1 year & 43 & 18.1 \\
1-5 years & 13 & 5.5 \\
6-10 years & \\
10 years and more &
\end{tabular}


In order to assess the aforementioned hypotheses, data were collected from 238 participants working in different sectors in Turkey. The sample was convenience-based. Of 238 respondents, $48.7 \%$ $(n=116)$ were female and the average age was 30.23 . On average, $63.4 \%$ of respondents $(n=151)$ had $1-5$ years' working experience in the current organization. Additionally, 54.2\% ( $n=129)$ worked in public sector while $45.8 \%$ ( $n=109)$ worked in private sector.

\subsection{Measures}

Job crafting. 15-item job crafting scale of Slemp and Vella-Brodrick (2013) was used for assessing job crafting. This scale consists of 5 items for task crafting (e.g., "change the scope or types of tasks that you complete at work"), 5 items for cognitive crafting (e.g., "remind yourself about the significance your work has for the success of the organization"), and 5 items for relational crafting (e.g., "make an effort to get to know people well at work"). Items were scored on a 5-point scale ranging from 1 (strongly disagree) to 5 (strongly agree).

Job-Related Affective Well-being. Job-related affective well-being was measured with a 12-item scale developed by Warr (1990a). The negative and positive emotions experienced in the past few weeks by the employees are evaluated with this scale. Example items are "tense, uneasy, worried" for negative emotions and "calm, contented, relaxed" for positive emotions. Items were scored on a 5-point scale ranging from 1 (never) to 5 (extremely often).

Organizational Identification. Organizational identification was assessed with a 6-item scale developed by Mael and Ashforth (1992). Example items are "when someone criticizes organization where I have been working, it feels like a personal insult." and "I am very interested in what others think about the organization where I have been working". Items were scored on a 5-point scale ranging from 1 (strongly disagree) to 5 (strongly agree).

\section{Analysis}

\subsection{Factor, Reliability and Validity Analysis}

Research data were analyzed by using structural equation modeling with AMOS 21 statistical package program for reliability and validity analysis (Fornell \& Larcker, 1981). The reliability of scales was assessed via Cronbach's Alpha and reliability coefficients of scales indicated sufficient reliability (Nunnally, 1978) and were ranged from 0.76 to 0.93 . Besides, the composite reliability score exhibited the threshold value of 0.60 ranging from 0.77 to 0.93 (Fornell \& Larcker, 1981).

Convergent and discriminant validation methods were followed to test the validity of the scales. With this regard, the measurement model with all variables was tested by confirmatory factor analysis and 6 items below the criterion value were excluded from the analysis. Results indicated that final model adequately fit the data $\left(\chi_{(309)}^{2}=652.652\right.$, comparative fit index $(C F I)=0.92$, Tucker-Lewis index $(T L I)=0.91$, incremental fit index $(\mathrm{IFI})=0.92$, parsimonious normed fit index is $(\mathrm{PNFI})=0.75$, root mean square error of approximation $(\mathrm{RMSEA})=0.06$ and $\chi^{2} / \mathrm{df}=2,112$ ). Factor loadings ranged from 0.66 to 0.91 , which exceeded the cut-off value (Hair, Black, Babin, \& Anderson, 2010) and average variance extracted (AVE) of each construct was between 0.51 and 0.71, demonstrating the convergent validity (Fornell \& Larcker, 1981; Bagozzi \& Yi, 1988). For discriminant validity, the square root of the AVE should be higher than the correlation between that construct and other constructs in the model (Fornell \& Larcker, 1981) and all construct fulfilled this requirement (see Table 3). 
Table 2. Factor Analysis, Convergent Validity, and Reliability of Constructs

\begin{tabular}{|c|c|c|c|c|}
\hline Factor/Item & $\begin{array}{l}\text { Factor } \\
\text { Loading }\end{array}$ & CR & AVE & $\begin{array}{l}\text { Cronbach's } \\
\text { Alpha }\end{array}$ \\
\hline Task Crafting & & 0.78 & 0.55 & 0.77 \\
\hline $\begin{array}{l}\text { JC_3: Introduce new work tasks that better suit my skills or } \\
\text { interests }\end{array}$ & 0.737 & & & \\
\hline JC_2: Change the scope/types of tasks that I complete at work & 0.732 & & & \\
\hline JC_1: Introduce new approaches to improve my work & 0.749 & & & \\
\hline Cognitive Crafting & & 0.84 & 0.51 & 0.83 \\
\hline JC_10: Reflect on the role my job has for my overall well-being & 0.761 & & & \\
\hline $\begin{array}{l}\text { JC_9: Think about the ways in which my work positively } \\
\text { impacts my life }\end{array}$ & 0.768 & & & \\
\hline $\begin{array}{l}\text { JC_8: Remind me of the importance of my work for the } \\
\text { broader community }\end{array}$ & 0.661 & & & \\
\hline $\begin{array}{l}\text { JC_7: Remind myself about the significance my work has for } \\
\text { the success of the organization }\end{array}$ & 0.700 & & & \\
\hline JC_6: Think about how my job gives my life purpose & 0.665 & & & \\
\hline Relational Crafting & & 0.77 & 0.63 & 0.76 \\
\hline JC_13: Organize special events in the workplace & 0.746 & & & \\
\hline JC_12: Organize or attend work-related social functions & 0.834 & & & \\
\hline Organizational Identification & & 0.91 & 0.63 & 0.90 \\
\hline $\begin{array}{l}\text { OI_1: When someone criticizes my organization, it feels like a } \\
\text { personal insult }\end{array}$ & 0.718 & & & \\
\hline $\begin{array}{l}\text { OI_2: I am very interested in what others think about my } \\
\text { organization }\end{array}$ & 0.713 & & & \\
\hline $\begin{array}{l}\text { OI_3: When I talk about this organization, I usually say 'we' } \\
\text { rather than 'they' }\end{array}$ & 0.748 & & & \\
\hline OI_4: This organization's successes are my successes & 0.873 & & & \\
\hline $\begin{array}{l}\text { OI_5: When someone praises this organization, it feels like a } \\
\text { personal compliment }\end{array}$ & 0.876 & & & \\
\hline $\begin{array}{l}\text { OI_6: If a story in the media criticized the organization, I would } \\
\text { feel embarrassed }\end{array}$ & 0.812 & & & \\
\hline Positive Affection & & 0.93 & 0.69 & 0.93 \\
\hline WB_1: My job made me feel "Calm" & 0.908 & & & \\
\hline WB_2: My job made me feel "Contented" & 0.914 & & & \\
\hline WB_5: My job made me feel "Relaxed" & 0.797 & & & \\
\hline WB_6: My job made me feel "Cheerful" & 0.820 & & & \\
\hline WB_9: My job made me feel "Enthusiastic" & 0.769 & & & \\
\hline WB_10: My job made me feel "Optimistic" & 0.767 & & & \\
\hline Negative Affection & & 0.92 & 0.71 & 0.92 \\
\hline WB_11: My job made me feel "Gloomy" & 0.827 & & & \\
\hline WB_8: My job made me feel "Depressed" & 0.816 & & & \\
\hline WB_7: My job made me feel "Worried" & 0.808 & & & \\
\hline WB_4: My job made me feel "Uneasy" & 0.902 & & & \\
\hline WB_3: My job made me feel "Tense" & 0.842 & & & \\
\hline
\end{tabular}

Table 3. Means, Standard Deviations, Correlations and The Square Root of AVE

\begin{tabular}{ccccccccc}
\hline Variables & Mean & SD & $\mathbf{1}$ & $\mathbf{2}$ & $\mathbf{3}$ & $\mathbf{4}$ & $\mathbf{5}$ & $\mathbf{6}$ \\
\hline TC & 3.75 & 0.70 & $(.74)$ & & & & & \\
CC & 4.04 & 0.68 & $0.36^{* *}$ & $(.71)$ & & & & \\
RC & 3.58 & 0.84 & $0.26^{* *}$ & $0.14^{* *}$ & $(.79)$ & & & \\
PA & 3.58 & 0.84 & $0.24^{* *}$ & $0.55^{* *}$ & $0.25^{* *}$ & $(.79)$ & & \\
NA & 2.69 & 1.00 & $-0.16^{* *}$ & $-0.29^{* *}$ & -0.03 & $-0.72^{* *}$ & $(.83)$ & \\
OI & 3.51 & 0.91 & $0.42^{* *}$ & $0.47^{* *}$ & $0.35^{* *}$ & $0.49^{* *}$ & $-0.24^{* *}$ & $(.84)$ \\
\hline
\end{tabular}

Notes: ${ }^{* *} \mathrm{p}=0.01 ; \mathrm{TC}=$ Task Crafting; $\mathrm{CC}=$ Cognitive Crafting; $\mathrm{RC}=$ Relational Crafting; $\mathrm{PA}=$

Positive Affection; NA= Negative Affection; OI = Organizational Identification; values along the diagonal are the square root of AVE. 
Table 3 shows the descriptive statistics and results of correlation analysis performed to determine the relationships between variables. Accordingly, task crafting $(r=0.24, p<0.01)$, cognitive crafting $(r=0.55$, $p<0.01)$, and relational crafting $(r=0.25, p<0.01)$ were significantly and positively correlated with positive affection. Task crafting $(r=-0.16, p<0.01)$ and cognitive crafting $(r=-0.29, p<0.01)$ were significantly and negatively correlated with negative affection while relational crafting $(r=-0.03, p>0.05)$ was not significantly correlated with negative affect. Moreover, task crafting $(r=.42, p<0.01)$, cognitive crafting $(r=.47, p<.01)$, and relational crafting $(r=0.35, p<.01)$ were significantly and positively correlated with organizational identification. positive affection $(r=0.49, p<0.01)$ was significantly and positively correlated with organizational identification while negative affection $(r=-0.24, p<0.01)$ was significantly and negatively correlated with organizational identification.

\subsection{Hypotheses Testing}

The bootstrapping method was performed to test the aforementioned hypotheses by virtue of providing more reliable results than the Baron and Kenny (1986) approach (Zhao, Lynch, \& Chen, 2010; Hayes, 2017). In this regard, mediation analyses were performed via PROCESS macro (Model 4; Hayes, 2017) and 5.000 bootstrapped samples with a $95 \%$ confidence interval.

Table 4. Direct Effects

\begin{tabular}{llcccc}
\hline & Paths & $\mathbf{R}^{\mathbf{2}}$ & $\boldsymbol{\beta}$ & $\mathbf{t}$ & $\mathbf{p}$ \\
\hline H1a & Task Crafting $\rightarrow$ Positive affection & 0.05 & 0.28 & 3.833 & 0.000 \\
H1b & Cognitive Crafting $\rightarrow$ Positive affection & 0.68 & 0.30 & 10.138 & 0.000 \\
H1c & Relational Crafting $\rightarrow$ Positive affection & 0.06 & 0.25 & 4.040 & 0.000 \\
H2a & Task Crafting $\rightarrow$ Negative affection & 0.02 & -0.23 & -2.574 & 0.000 \\
H2b & Cognitive Crafting $\rightarrow$ Negative affection & 0.08 & -0.43 & -4.768 & 0.000 \\
H2c & Relational Crafting $\rightarrow$ Negative affection & 0.01 & -0.04 & $-0,590$ & $\mathbf{0 . 5 5 5}$ \\
H3a & Task Crafting $\rightarrow$ Identification & 0.18 & 0.54 & 7.208 & 0.000 \\
H3b & Cognitive Crafting $\rightarrow$ Identification & 0.22 & 0.62 & 8.173 & 0.000 \\
H3c & Relational Crafting $\rightarrow$ Identification & 0.12 & 0.31 & 5.809 & 0.000 \\
H4a & Positive affection $\rightarrow$ Identification & 0.24 & 0.49 & 8.818 & 0.000 \\
H4b & Negative affection $\rightarrow$ Identification & 0.06 & -0.24 & -3.908 & 0.000 \\
\hline
\end{tabular}

According to Table 4, the effect of job crafting on positive affection was investigated and results revealed that task crafting $(\beta=0.28, p<0.001)$, cognitive crafting $(\beta=0.30, p<0.001)$ and relational crafting $(\beta=0.25, p<0.001)$ were significantly related to positive affection, supporting $H 1 a, H 1 b$, and $H 1 c$.

Besides, the effect of job crafting on negative affection was investigated and results revealed that task crafting $(\beta=-0.23, p<0.001)$ and cognitive crafting $(\beta=-0.43, p<0.001)$ were significantly and negatively related to negative affection, supporting $\mathrm{H} 2 \mathrm{a}$ and $\mathrm{H} 2 \mathrm{~b}$. Contrarily, a significant relationship was not found between relational crafting ( $\beta=-0.04, p=0.555)$ and negative affection. Therefore, $\mathrm{H} 2 \mathrm{c}$ was rejected.

Additionally, there was a positive and significant relationship between organizational identification and task crafting $(\beta=0.54, p<0.001)$, cognitive crafting $(\beta=0.62, p=0.000)$, and relational crafting $(\beta=0.31$, $p<0.001)$, supporting $\mathrm{H} 3 \mathrm{a}, \mathrm{H} 3 \mathrm{~b}$, and $\mathrm{H} 3 \mathrm{c}$.

There was also a positive and significant relationship between positive affection and organizational identification ( $\beta=0.49 ; p<0.001$ ), supporting $\mathrm{H} 4 \mathrm{a}$. Besides, there was a negative and significant relationship between negative affection and organizational identification $(\beta=-0.24 ; p<0.001)$, supporting $H 4 b$.

Table 5. Mediating Analyses for Positive Affection

\begin{tabular}{llcccc}
\hline & Paths & $\mathbf{R}^{2}$ & $\boldsymbol{\beta}$ & $\mathbf{t}$ & $\mathbf{p}$ \\
\hline H5a & Task Crafting $\rightarrow$ Identification & 0.34 & 0.41 & 5.944 & 0.000 \\
H5b & Cognitive Crafting $\rightarrow$ Identification & 0.30 & 0.37 & 4.299 & 0.000 \\
H5c & Relational Crafting $\rightarrow$ Identification & 0.30 & 0.21 & 4.331 & 0.000 \\
\hline
\end{tabular}


Further, positive affection reduced the effect of job crafting $(\beta=0.41 ; p<0.001$ for task crafting; $\beta=0.37 ; p<0.001$ for cognitive crafting; $\beta=0.21 ; p<0.001$ for relational crafting) on organizational identification, and inclusion of positive affection in the model increased the $\mathrm{R}^{2}$ of organizational identification $\left(R^{2}=0.34\right.$ for task crafting; $R^{2}=0.30$ for cognitive crafting; $R^{2}=0.30$ for relational crafting). In this context, positive affection had a partial mediating effect.

Table 6. Mediating Analyses for Negative Affection

\begin{tabular}{llcccc}
\hline & Paths & $\mathbf{R}^{\mathbf{2}}$ & $\boldsymbol{\beta}$ & $\mathbf{t}$ & $\mathbf{p}$ \\
\hline H6a & Task Crafting $\rightarrow$ Identification & 0.21 & 0.50 & 6.725 & 0.000 \\
H6b & Cognitive Crafting $\rightarrow$ Identification & 0.30 & 0.57 & 7.270 & 0.000 \\
\hline
\end{tabular}

Further, negative affection reduced the effect of job crafting $(\beta=0.50 ; p<0.001$ for task crafting; $\beta=0.57 ; p<0.001$ for cognitive crafting) on organizational identification, and inclusion of negative affection in the model increased the $R^{2}$ of organizational identification $\left(R^{2}=0.21\right.$ for task crafting; $R^{2}=0.30$ for cognitive crafting). In this context, negative affection had a partial mediating effect.

Table 7. Significance Values of Indirect Effects

\begin{tabular}{lcc}
\hline \multirow{2}{*}{ Indirect effect } & \multicolumn{2}{c}{$\mathbf{9 5 \%} \mathbf{C l}$} \\
\cline { 2 - 3 } & Lower & Upper \\
\hline Task Crafting $\rightarrow$ Positive Affection $\rightarrow$ Identification & 0.059 & 0.224 \\
Cognitive Crafting $\rightarrow$ Positive Affection $\rightarrow$ Identification & 0.151 & 0.376 \\
Relational Crafting $\rightarrow$ Positive Affection $\rightarrow$ Identification & 0.116 & 0.312 \\
Task Crafting $\rightarrow$ Negative Affection $\rightarrow$ Identification & 0.006 & 0.092 \\
Cognitive Crafting $\rightarrow$ Negative Affection $\rightarrow$ Identification & 0.002 & 0.107 \\
\hline
\end{tabular}

Table 7 has shown the results of significant values of indirect effect and it was concluded that the indirect effect of positive and negative affection was significant due to the lack of zero in the specified ranges of confidence intervals (MacKinnon, Lockwood and Williams, 2004). In other words, positive and negative affection have a partially mediating effect in the relationship between job crafting and organizational identification, supporting $\mathrm{H} 5 \mathrm{a}, \mathrm{H} 5 \mathrm{~b}, \mathrm{H} 5 \mathrm{c}, \mathrm{H} 6 \mathrm{a}$, and $\mathrm{H} 6 \mathrm{~b}$. However, based on the findings, $\mathrm{H} 6 \mathrm{c}$ was rejected.

\section{Conclusion}

The purpose of the current study was to delineate the relationship between job crafting and organizational identification via the mediating role of employees' affective well-being. In this context, the current study found that job crafting influences the employees' affective well-being. In other words, based on the findings, employees who craft their job in terms of task, cognition, and relations likely to experience more positive affective well-being. On the other hand, task and cognitive crafting prohibit the feeling of negative work-related affection while relational crafting has no impact on the negative affective well-being. Concordantly, Tims et al. (2013), Slemp et al. (2015), and Plomp et al. (2016) revealed that, through job crafting, employees can shape their jobs compliance with their abilities, skills, interest, and values which in turn increase their well-being.

According to the findings, employees tend to identify themselves with their organizations in the existence of an opportunity to craft their jobs on physical, relational and cognitive aspects. This empirical evidence supports the argument that crafting yields a variety of positive organizational outcomes such as increased satisfaction, commitment, and engagement with their organizations (Tims and Bakker, 2010; Tims et al., 2016; Rudolph et al., 2017). In this context, the conclusion can be drawn that job crafting behaviors of employees enable them to develop positive perceptions toward their organizations, and thus they feel more identified with their organization because of providing opportunities to change their job boundaries and freedom by the organization. 
Besides, the mediating role of affective well-being in the relationship between job crafting and organizational identification has been investigated. Results show that when employees experience more positive affection and less negative affection through the opportunities which help them to craft and design their jobs, they inclined to perceive better organizational identification. Based on this result, the conclusion can be drawn that employees who able to change tasks, relations, and cognitions proactively in line with their own needs tend to experience more positive affections because they have been provided opportunities to craft by their organization. Therefore, considering the view of social identity theory (Tajfel, 1974; Tajfel \& Turner, 1985), reaching a better state of psychological health and affective well-being leads employees to develop a positive sense of belonging and organizational identification which helps employees to enhance beneficial organizational behaviors and outcomes.

\subsection{Limitations and Future Studies}

There are some limitations of this study. First, the data collection process was carried out only on the participants who worked in Turkey. It is possible to generalize the results through a homogeneous and wider sample population in terms of cultural context, generation and professional background in future research.

This study is also cross-sectional reflecting the thoughts of employees at a certain moment. It may be suggested that future studies should be performed longitudinally. Another limitation of the research is related to the data collection method. In future studies, the results can be evaluated by applying qualitative data analysis including interview through data collection methods.

Besides, the relationship between job crafting, affective well-being, and organizational identification has been examined within the scope of the current study and the effects of different variables such as organizational culture and different leadership styles on the job crafting may also be emphasized for contributing the expansion of the related literature. On the other hand, it may be beneficial to examine the effect of job crafting on overqualification perception of the employees. It is possible to state that employees having the ability to change their task, relations, and thoughts may tend to perceive themselves as overqualified and it can be examined in detail how this overqualification perception as a result of job crafting will have an impact on employees' intention to leave or stay at work.

\section{References}

Ashforth, B. E., \& Mael, F. (1989). Social identity theory and the organization. Academy of Management Review, 14(1), 20-39.

Avanzi, L., van Dick, R., Fraccaroli, F., \& Sarchielli, G. (2012). The downside of organizational identification: Relations between identification, workaholism and well-being. Work and Stress, 26(3), 289-307.

Bacaksiz, F. E., Tuna, R., \& Seren, A. K. H. (2017). The relationships between organisational identification, job performance, and job crafting: A study among nurses. International Journal of Caring Sciences, 10(1), 251-259.

Bagozzi, R. P., \& Yi, Y. (1988). On the evaluation of structural equation models. Journal of the Academy of Marketing Science, 16(1), 74-94.

Bakker, A. B., \& Demerouti, E. (2007). The job demands-resources model: State of the art. Journal of Managerial Psychology, 22(3), 309-328.

Bakker, A. B., \& Demerouti, E. (2017). Job demands-resources theory: Taking stock and looking forward. Journal of Occupational Health Psychology, 22(3), 273-285.

Bakker, A. B., Tims, M., \& Derks, D. (2012). Proactive personality and job performance: The role of job crafting and work engagement. Human Relations, 65(10), 1359-1378.

Baron, R. M., \& Kenny, D. A. (1986). The moderator-mediator variable distinction in social psychological research: Conceptual, strategic, and statistical considerations. Journal of Personality and Social Psychology, 51(6), 1173.

Berg, J. M., Wrzesniewski, A., \& Dutton, J. E. (2010). Perceiving and responding to challenges in job crafting at different ranks: When proactivity requires adaptivity. Journal of Organizational Behavior, 31(2-3), 158-186. 
Bipp, T., \& Demerouti, E. (2015). Which employees craft their jobs and how? Basic dimensions of personality and employees' job crafting behaviour. Journal of occupational and organizational psychology, 88(4), 631-655.

Costantini, A., \& Sartori, R. (2018). The intertwined relationship between job crafting, work-related positive emotions, and work engagement: Evidence from a positive psychology intervention study. The Open Psychology Journal, 11(1), 210-221.

De Beer, L. T., Tims, M., \& Bakker, A. B. (2016). Job crafting and its impact on work engagement and job satisfaction in mining and manufacturing. South African Journal of Economic and Management Sciences, 19(3), 400-412.

Demerouti, E. (2014). Design your own job through job crafting. European psychologist, 19(4), 237-243.

Demerouti, E., Nachreiner, F., Bakker, A. B., \& Schaufeli, W. B. (2001). The job demands-resources model of burnout. Journal of Applied Psychology, 86(3), 499-512.

Fornell, C., \& Larcker, D. F. (1981). Evaluating structural equation models with unobservable variables and measurement error. Journal of Marketing Research, 18(1), 39-50.

Hackman, J. R., \& Oldham, G. R. (1980). Work redesign. Reading, MA: Addison-Wesley.

Hair, J. F., Black, W. C., Babin, B. J., \& Anderson, R. E. (2010). Multivariate data analysis (Global edition). Upper Saddle River, NJ: Prentice Hall.

Hayes, A. F. (2017). Introduction to mediation, moderation, and conditional process analysis: A regression-based approach. New York, NY: Guilford Publications.

Hur, W. M., Shin, Y., Rhee, S. Y., \& Kim, H. (2017). Organizational virtuousness perceptions and task crafting: The mediating roles of organizational identification and work engagement. Career Development International, 22(4), 436-459.

Kanten, P. (2014). The antecedents of job crafting: Perceived organizational support, job characteristics and self-efficacy. European Journal of Business and Social Sciences, 3(5), 113-128.

Kerse, G. (2017). İş becerikliliği (job crafting) ölçeğini Türkçe'ye uyarlama ve duygusal tükenme ile ilişkisini belirleme. işletme Araştırmaları Dergisi, 9(4), 283-304.

Kerse, G. (2018). The impact of job crafting on person-job fit:"I am compatible with my work because i can make changes in my work." Atatürk Üniversitesi Iktisadi ve Idari Bilimler Dergisi, 32(4), 941-958.

Kim, H., Im, J., \& Qu, H. (2018). Exploring antecedents and consequences of job crafting. International Journal of Hospitality Management, 75, 18-26.

Klimchak, M., Carsten, M., Morrell, D., \& MacKenzie, W. I. (2016). Employee entitlement and proactive work behaviors: The moderating effects of narcissism and organizational identification. Journal of Leadership and Organizational Studies, 23(4), 387-396.

Leana, C., Appelbaum, E., \& Shevchuk, I. (2009). Work process and quality of care in early childhood education: The role of job crafting. Academy of Management Journal, 52(6), 1169-1192.

Mael, F. A., \& Ashforth, B. E. (1992). Alumni and their alma mater: A partial test of the reformulated model. Journal of Organizational Behavior, 13(2), 103-123.

MacKinnon, D. P., Lockwood, C. M., \& Williams, J. (2004). Confidence limits for the indirect effect: Distribution of the product and resampling methods. Multivariate Behavioral Research, 39(1), 99-128.

Mäkikangas, A., Feldt, T., \& Kinnunen, U. (2007). Warr's scale of job-related affective well-being: A longitudinal examination of its structure and relationships with work characteristics. Work and Stress, 21(3), 197-219.

Niessen, C., Weseler, D., \& Kostova, P. (2016). When and why do individuals craft their jobs? The role of individual motivation and work characteristics for job crafting. Human Relations, 69(6), 1287-1313.

Nunnally, J. C. (1978). Psychometric methods. New York, NY: McGraw Hill.

Oldham, G. R., \& Hackman, J. R. (2010). Not what it was and not what it will be: The future of job design research. Journal of Organizational Behavior, 31(2-3), 463-479.

Parker, S. K., Bindl, U. K., \& Strauss, K. (2010). Making things happen: A model of proactive motivation. Journal of Management, 36(4), 827-856.

Plomp, J., Tims, M., Akkermans, J., Khapova, S. N., Jansen, P. G. W., \& Bakker, A. B. (2016). Career competencies and job crafting: How proactive employees influence their well-being. Career Development International, 21(6), $587-602$.

Riketta, M. (2005). Organizational identification: A meta-analysis. Journal of Vocational Behavior, 66(2), 358-384.

Rofcanin, Y., Berber, A., Koch, S., \& Sevinc, L. (2016). Job crafting and I-deals: A study testing the nomological network of proactive behaviors. International Journal of Human Resource Management, 27(22), 2695-2726. 
Rudolph, C. W., Katz, I. M., Lavigne, K. N., \& Zacher, H. (2017). Job crafting: A meta-analysis of relationships with individual differences, job characteristics, and work outcomes. Journal of Vocational Behavior, 102(314), 112138.

Slemp, G. R., \& Vella-Brodrick, D. A. (2013). The job crafting questionnaire: A new scale to measure the extent to which employees engage in job crafting. International Journal of Wellbeing, 3(2), 126-146.

Slemp, G. R., \& Vella-Brodrick, D. A. (2014). Optimising employee mental health: The relationship between intrinsic need satisfaction, job crafting, and employee well-being. Journal of Happiness Studies, 15(4), 957-977.

Slemp, G. R., Kern, M. L., \& Vella-Brodrick, D. A. (2015). Workplace well-being: The role of job crafting and autonomy support. Psychology of Well-being, 5(1): 7.

Tajfel, H. \& Turner, J. C. (1985). The social identity theory of intergroup behavior. In: Worchel, S. and Austin, W. G. (Eds) Psychology of Intergroup Relations, 2nd ed., Chicago: Nelson-Hall.

Tajfel, H. (1974). Social identity and intergroup behavior. Social Science Information, 13(2), 65-93.

Tims, M., \& Bakker, A. B. (2010). Job crafting: Towards a new model of individual job redesign. South African Journal of Industrial Psychology, 36(2), 1-9.

Tims, M., Bakker, A. B., \& Derks, D. (2012). Development and validation of the job crafting scale. Journal of Vocational Behavior, 80(1), 173-186.

Tims, M., Bakker, A. B., \& Derks, D. (2013). The impact of job crafting on job demands, job resources, and well-being. Journal of Occupational Health Psychology, 18(2), 230-240.

Tims, M., Derks, D., \& Bakker, A. B. (2016). Job crafting and its relationships with person-job fit and meaningfulness: A three-wave study. Journal of Vocational Behavior, 92, 44-53.

Uysal, B., Özçelik, G., \& Uyargil, C. B. (2018). Bireysel iş yapılandırmanın sonuçları: Bireysel iş yapılandırmanın psikolojik sermaye ve işe adanmışlık üzerindeki etkisinin değerlendirilmesi. Yönetim Bilimleri Dergisi, 16(32), 651-666.

Van den Heuvel, M., Demerouti, E., \& Peeters, M. C. W. (2015). The job crafting intervention: Effects on job resources, self-efficacy, and affective well-being. Journal of Occupational and Organizational Psychology, 88(3), 511-532.

Van Katwyk, P. T., Fox, S., Spector, P. E., \& Kelloway, E. K. (2000). Using the Job-Related Affective Well-Being Scale (JAWS) to investigate affective responses to work stressors. Journal of Occupational Health Psychology, 5(2), $219-230$.

Van Knippenberg, D., \& Schie, E. C. M. (2000). Foci and correlates of organizational identification. Journal of Occupational and Organizational Psychology, 73(2), 137-147.

Wang, H. J., Demerouti, E., \& Le Blanc, P. (2017). Transformational leadership, adaptability, and job crafting: The moderating role of organizational identification. Journal of Vocational Behavior, 100, 185-195.

Warr, P. (1987). Work, unemployment, and mental health. Oxford: Oxford University Press.

Warr, P. (1990a). The measurement of well-being and other aspects of mental health. Journal of Occupational Psychology, 63(3), 193-210.

Warr, P. (1990b). Decision latitude, job demands, and employee well-being. Work and Stress, 4(4), $285-294$.

Wegge, J., Van Dick, R., Fisher, G., Wecking, C., \& Moltzen, K. (2006). Work motivation, organisational identification, and well-being in call centre work. Work and Stress, 20(1), 60-83.

Wrzesniewski, A., \& Dutton, J. E. (2001). Crafting a job: Revisioning employees as active crafters of their work. Academy of Management Review, 26(2), 179-201.

Wrzesniewski, A., Lobuglio, N., Dutton, J. E., \& Berg, J. M. (2013). Job crafting and cultivating positive meaning and identity in work. Advances in Positive Organizational Psychology, 1, 281-302.

Zhao, X., Lynch Jr, J. G., \& Chen, Q. (2010). Reconsidering Baron and Kenny: Myths and truths about mediation analysis. Journal of Consumer Research, 37(2), 197-206. 